\title{
Shoe-makers' polyneuropathy in Italy: the aetiological problem
}

\author{
G. ABBRITTI ${ }^{1}$, A. SIRACUSA ${ }^{1}$, C. CIANCHETTI ${ }^{2 *}$, C. A. COLI, \\ F. CURRADI ${ }^{1}$, G. F. PERTICONI ${ }^{2}$, and F. DEROSA ${ }^{3}$ \\ Institute of Occupational Medicine, University of Perugia, Policlinico, 06100 Perugia $^{1}$; Service of \\ Neurophysiopathology, Regional Hospital, Perugia ${ }^{2}$; Provincial Laboratory of Hygiene, \\ Section of Chemistry, Pesaro, Italy ${ }^{3}$
}

\begin{abstract}
Abbritti, G., Siracusa, A., Cianchetti, C., Coli, C. A., Curradi, F., Perticoni, G. F., and De Rosa, F. (1976). British Journal of Industrial Medicine, 33, 92-99. Shoe-makers' polyneuropathy in Italy: the aetiological problem. Since 1957, when the first cases of the so-called shoe-makers' toxic polyneuropathy were reported, nearly 400 cases have been described in the Italian literature. The substance that was considered to be responsible for the disease was triorthocresylphosphate (TOCP) contained in glues, artificial leathers, and some types of paints. However numerous chemical analyses of glues and leathers taken from factories where cases of the disease occurred have shown that in almost all instances little or no TOCP was present. In addition the disease manifests itself more frequently during winter and spring and this is not consistent with the absorption of the causative agent through the skin and/or gastrointestinal tract. In order to clarify the aetiology of the disease 122 workers in the shoe industry affected by toxic polyneuropathy during the period 1971-74 were studied. Workplaces where cases of polyneuropathy had occurred were visited and samples of glues and solvents were taken for chemical analysis. The polyneuropathy chiefly affects workers engaged in glueing and in the cleaning process, but it also affects those who do not have direct contact with glues or solvents. The disease is more common in women (68\%) than in men (32\%) and, in its more severe form, begins with overwhelming prevalence during winter and early spring regardless of the job performed. No direct relationship has been found between the severity of the disease and the number of years of work in the shoe industry or of specific exposure (that is the number of years of work in the activity performed at the onset of the disease). The polyneuropathy is found almost exclusively among workers of the artisan type in small shoe factories, where standards of hygiene are low. Chemical analysis of glues and cleaning fluids collected from five different factories, where 20 cases of polyneuropathy occurred, showed the presence of paraffin hydrocarbons with a low boiling point (pentane, 2-methylpentane, 3-methyl-pentane, $n$-hexane, etc.) in concentrations of more than $80 \%$ by weight.
\end{abstract}

Since 1957, when the first nine cases of polyneuropathy were reported among workers in different shoe factories (Isotti and Saraval, 1957), nearly 400 cases have been reported on in Italy. Table 1 shows the cases described during the period 1957-73. From an analysis of this table it is evident that the

* Present address: Clinic of Neurology, University of Cagliari, Italy. frequency of the disease is steadily increasing. The year 1968 seemed to be the worst but this was probably because the Italian Congress of Occupational Health allocated one session to the study of the disease, so that many cases were reported on that occasion. The polyneuropathy affects mainly, although not exclusively, workers in the shoe and leather industry. The disease manifests itself most 
TABLE 1

Shoe-Makers' Polyneuropathy IN ITALY

\begin{tabular}{|c|c|c|c|c|c|c|c|}
\hline \multicolumn{8}{|c|}{ Reported cases from 1957 to 1973} \\
\hline \multicolumn{3}{|c|}{ Authors } & $\begin{array}{c}\text { Year of } \\
\text { publication }\end{array}$ & $\begin{array}{c}\text { Total } \\
\text { no. cases }\end{array}$ & $\begin{array}{l}\text { No. cases in } \\
\text { shoe and leather } \\
\text { industry }\end{array}$ & $\begin{array}{c}\text { Season of } \\
\text { maximum frequency }\end{array}$ & $\begin{array}{c}\text { Causative substance } \\
\text { suspected }\end{array}$ \\
\hline \multirow{10}{*}{\multicolumn{2}{|c|}{$\begin{array}{l}\text { Isotti and Saraval ... } \\
\text { Isotti and Saraval ... } \\
\text { Gatti and Saraval ... } \\
\text { Fabiani and Bedogni } \\
\text { Pretolani and Scotti } \\
\text { Mazzella di Bosco ... } \\
\text { Pinelli and Tonali } \\
\text { Gherardi .. } \\
\text { Del Greco and Cecchini }\end{array}$}} & $\ldots$ & 1957 & 9 & 9 & ? & $?$ \\
\hline & & . & $1958\}$ & 19 & $?$ & $?$ & TOCP \\
\hline & & .. & $1960\}$ & 19 & ? & $?$ & $?$ \\
\hline & & . & 1962 & 6 & 6 & $?$ & $?$ \\
\hline & & .. & 1963 & 13 & 13 & Winter-Spring & TOCP \\
\hline & & . & 1964 & 8 & 8 & Winter-Spring & TOCP \\
\hline & & $\ldots$ & 1964 & 1 & 1 & Spring & TOCP \\
\hline & & $\ldots$ & 1965 & 15 & 15 & Winter & TOCP \\
\hline & & . & 1966 & 8 & 8 & Winter-Spring & $?$ \\
\hline & $\ldots$ & $\ldots$ & 1967 & 5 & 5 & Winter-Spring & TOCP + Solvents \\
\hline Leoni $\quad \ldots$ & .. & . & 1967 & 6 & 5 & Winter-Spring & ? \\
\hline Crepet et al. & .. & .. & 1968 & 49 & 48 & $?$ & TOCP \\
\hline Cappellini et al. & & $\ldots$ & 1968 & 47 & 25 & Winter-Spring & TOCP \\
\hline Maugeri and Can & dura & .. & 1968 & 11 & 11 & $?$ & TOCP \\
\hline Ambrosetto.. & $\ldots$ & . & 1968 & 10 & 10 & $?$ & TOCP \\
\hline Ruggerini and $\mathrm{Te}$ & & . & 1968 & 30 & 0 & Winter-Spring & TOCP \\
\hline Marroni $\quad \ldots$ & $\ldots$ & .. & $1968 a$ & 5 & 5 & Winter-Spring & TOCP \\
\hline Marroni $\quad .$. & $\ldots$ & .. & $1968 \mathrm{~b}$ & 1 & 0 & $?$ & TOCP \\
\hline D'Errico et al. & . & . & 1968 & 7 & 7 & Winter-Spring & TOCP \\
\hline Graev et al. & .. & .. & 1971 & 8 & 7 & Winter-Spring & TOCP \\
\hline Faggi et al. & . & . & 1971 & 14 & 14 & $?$ & TOCP \\
\hline Carnevale et al. & $\ldots$ & . & 1973 & 2 & 2 & Winter-Spring & Solvents (Hexane) \\
\hline Montanari .. & $\ldots$ & . & 1976 & 72 & 72 & Winter-Spring & $?$ \\
\hline Battistini et al. & . & . & 1973 & 6 & 6 & $?$ & $?$ \\
\hline Barone et al. & & & 1973 & 50 & 50 & Winter-Spring & TOCP \\
\hline
\end{tabular}

? Not reported or unknown

frequently during winter and spring, and the substance considered responsible for the disease was triorthocresylphosphate (TOCP), which is contained in glues, artificial leathers, and some types of paints.

The hypothesis that TOCP is involved in the aetiology has been supported as follows (Cappellini, Chiappino, and Zurlo, 1968):

Triorthocresylphosphate is used in the production of polyvinyl chloride plastics, paints, glues, and artificial leathers and is sometimes added to old stocks of glue to reactivate them; the clinical picture and the histopathological changes found among workers affected by this disease were similar to those found in patients with polyneuropathy due to exposure to TOCP which was not related to occupation, and to those found in experimental animals given TOCP; other known neurotoxic substances in the working environment that could have caused the disease were not found.

From a retrospective analysis of the reports there are several elements which in our opinion cast doubt on the importance of TOCP as the only or principal cause of the disease.
Numerous chemical analyses of the glues and leathers taken from factories where cases of the disease were found have shown that in almost all instances, little or no TOCP was present (Crepet et al., 1968; Cappellini et al., 1968). Moreover the disease manifests itself more frequently during winter and spring, and this is not consistent with the hypothesis of absorption of the causal agent through the skin and/or gastrointestinal tract.

In order to clarify the aetiology of the disease we studied 122 shoe industry workers affected by polyneuropathy during the period 1971-74.

This paper concerns the relationship between occupation and the frequency and severity of the polyneuropathy, between the severity of the disease and the age, sex, and length of exposure; and the relationship between the time of year and the onset and severity of the disease. The composition of glues and solvents used in different shoe factories in which there were 20 cases of polyneuropathy is also reported, together with some observations concerning these work places. The clinical and electromyographic details are given in another paper (Cianchetti et al., in preparation). 
Methods

Detailed information about the work place, the type of material used, the job performed at the onset of the disease and in previous years and a detailed description of the symptoms, their order of appearance and evolution was obtained from every worker affected by polyneuropathy.

All patients were given an electromyographic examination in addition to laboratory investigations necessary to exclude the presence of other diseases that could cause polyneuropathy, such as diabetes, chronic alcoholism, etc. In none of the cases observed was there evidence of any past contact with chemicals such as lead, arsenic, carbon disulphide, etc. or drugs such as sulphonamides, deemed capable of causing polyneuropathy.

When patients came under observation within a few days after stopping work, we visited their work places and took samples of glues and solvents used for chemical analysis.

The patients were divided into three groups according to the severity of the polyneuropathy, using as the reference parameter the maximum motor conduction velocity (MCV/max) of the peroneal nerve (PN):

Group I: with $\mathrm{MCV} / \mathrm{max}$ of PN less than $35 \mathrm{~m} / \mathrm{s}$;

Group II: with MCV/max of PN between 35 and $44 \mathrm{~m} / \mathrm{s}$; Group III: with $\mathrm{MCV} / \mathrm{max}$ of $\mathrm{PN}$ equal or greater than $45 \mathrm{~m} / \mathrm{s}$, but with clear electromyographic signs of neurogenic alteration (reduced interference pattern; increase of polyphasic and irregular potentials; increase of voltage and duration; spontaneous activity of denervated fibres).

The peroneal nerve was chosen as the reference parameter because it was almost always shown to be the nerve with maximum proportional reduction of $\mathrm{MCV}$ values. The patients we examined came from 72 shoe factories in different provinces and regions of Italy (Table 2) and this suggests that the disease is caused by substances in widespread use.

\section{Results}

Table 3 shows the relationship between occupation and the frequency and severity of polyneuropathy. The jobs which carried the major risk were glueing and cleaning of the finished goods with solvents. In fact $71.3 \%$ of the patients performed these two jobs in which usually only $20-25 \%$ of workers are engaged, whereas the remaining $28.7 \%$ of the patients worked in more than 10 other jobs into which the productive cycle of the shoe industry is divided. It is also worth noting that the patients in the last group had no direct contact with glues and solvents.

In Table 4 the relationship between the severity of the disease and age, sex, and specific and total length of exposure is analysed. The age of patients ranged from 15 to 59 years with an average of 34.8 years. No significant age differences exist between the three groups. The disease was most frequently found among women $(68 \%)$ probably because they are mainly engaged in duties which carry the major risk (glueing and cleaning). No direct relationship existed between the severity of the disease and length of total exposure (the total number of years of work in the shoe industry) or specific exposure (the number of years of work in the activity performed at the onset of the disease).

The mean total exposure was 5.4 years in Group I, 6.8 years in Group II, and 11.7 years in Group III; the mean specific exposure was of $3.4,1 \cdot 7$, and 3 years respectively in the three groups. Some workers were affected by the disease after only one month of work. Fig. 1 shows the relationship between the time of year and the onset and severity of the disease. The most serious form of the disease (Groups I and II) begins with overwhelming prevalence in the winter and early spring; $83 \%$ of the cases in Group I and $74 \%$ of those in Group II were first manifested during the first four months of the year. The less serious form (Group III) manifests itself during all periods of the year with almost equal frequency. It is necessary to point out, however, that sometimes it was difficult for patients in this group to state with absolute certainty the month when the symptoms first began, as this was usually many months earlier.

The patients in Groups I and II were therefore

TABLE 2

Distribution of Cases of Polyneuropathy

\begin{tabular}{|c|c|c|c|c|c|c|c|}
\hline \multicolumn{4}{|c|}{ Origin } & \multirow{2}{*}{$\begin{array}{c}\text { Factories with cases } \\
\text { of polyneuropathy (no.) }\end{array}$} & \multirow{2}{*}{$\%$} & \multirow{2}{*}{$\begin{array}{c}\text { Cases of } \\
\text { polyneuropathy (no.) }\end{array}$} & \multirow{2}{*}{$\%$} \\
\hline & ion & & Province & & & & \\
\hline $\begin{array}{l}\text { Marche } \\
\text { Umbria } \\
\text { Toscana }\end{array}$ & $\begin{array}{l}\cdots \\
\cdots \\
\cdots\end{array}$ & $\begin{array}{l}\cdots \\
\cdots\end{array}$ & $\begin{array}{l}\text { Ascoli Piceno } \\
\text { Macerata } \\
\text { Pesaro } \\
\text { Perugia } \\
\text { Terni } \\
\text { Arezzo } \\
\text { Siena }\end{array}$ & $\begin{array}{r}46 \\
15 \\
3 \\
4 \\
1 \\
2 \\
1\end{array}$ & $\begin{array}{r}63 \cdot 9 \\
20 \cdot 8 \\
4 \cdot 2 \\
5 \cdot 5 \\
1 \cdot 4 \\
2 \cdot 8 \\
1 \cdot 4\end{array}$ & $\begin{array}{r}71 \\
22 \\
13 \\
7 \\
1 \\
7 \\
1\end{array}$ & $\begin{array}{r}58 \cdot 2 \\
18 \cdot 1 \\
10 \cdot 6 \\
5 \cdot 7 \\
0 \cdot 8 \\
5 \cdot 7 \\
0.8\end{array}$ \\
\hline & & & Total & 72 & 100 & 122 & 100 \\
\hline
\end{tabular}


TABLE 3

Relationship between Occupation and SeVerity of Polyneuropathy

\begin{tabular}{|c|c|c|c|c|c|}
\hline \multirow{3}{*}{ Occupation } & \multirow{3}{*}{ Cases (no.) } & \multirow{3}{*}{$\%$ of total } & \multicolumn{3}{|c|}{ Severity of polyneuropathy } \\
\hline & & & \multicolumn{3}{|c|}{$M M C V$ of $P N$} \\
\hline & & & $\begin{array}{c}\text { Group I } \\
(<35 \mathrm{~m} / \mathrm{s})\end{array}$ & $\underset{(35-44 \mathrm{~m} / \mathrm{s})}{\text { Group II }}$ & $\begin{array}{c}\text { Group III } \\
(\gg 45 \mathrm{~m} / \mathrm{s})\end{array}$ \\
\hline $\begin{array}{lll}\text { Glueing } & \ldots & \ldots \\
\text { Cleaning } & \ldots & \ldots \\
\text { Other jobs } & \ldots & \ldots \\
\text { (without direct contact } \\
\text { with glues or solvents) }\end{array}$ & $\begin{array}{l}56 \\
31 \\
35\end{array}$ & $\begin{array}{l}45 \cdot 9 \\
25 \cdot 4 \\
28 \cdot 7\end{array}$ & $\begin{array}{r}15 \\
6 \\
16\end{array}$ & $\begin{array}{r}19 \\
19 \\
4\end{array}$ & $\begin{array}{r}22 \\
6 \\
15\end{array}$ \\
\hline Total . & 122 & 100 & 37 & 42 & 43 \\
\hline
\end{tabular}

TABLE 4

Relationship between Severity of Polyneuropathy and Age, Sex, Length of Exposure

\begin{tabular}{|c|c|c|c|c|c|c|c|c|c|c|c|}
\hline \multirow{3}{*}{\multicolumn{4}{|c|}{$\begin{array}{c}\text { Severity of polyneuropathy } \\
M M C V \text { of } P N\end{array}$}} & & & \multirow{2}{*}{\multicolumn{2}{|c|}{ Sex }} & \multicolumn{4}{|c|}{ Length of exposure (years) } \\
\hline & & & & \multicolumn{2}{|c|}{ Age (years) } & & & \multicolumn{2}{|c|}{ Total } & \multicolumn{2}{|c|}{ Specific } \\
\hline & & & & Mean & Range & $\begin{array}{c}M \\
\text { (no.) }\end{array}$ & $\begin{array}{c}F \\
(\text { no. })\end{array}$ & Mean & Range & Mean & Range \\
\hline $\begin{array}{l}\text { Group I } \\
<35 \mathrm{~m} / \mathrm{s}\end{array}$ & $\cdots$ & $\cdots$ & . & $31 \cdot 4$ & $15-54$ & 8 & 29 & $5 \cdot 4$ & $0 \cdot 1-9$ & 3 & $0 \cdot 1-9$ \\
\hline $\begin{array}{l}\text { Group II } \\
35-44 \mathrm{~m} / \mathrm{s}\end{array}$ & $\cdots$ & $\cdots$ & . & 35 & $15-52$ & 9 & 33 & $6 \cdot 8$ & $0 \cdot 1-22$ & $4 \cdot 1$ & $0 \cdot 1-10$ \\
\hline \multirow[t]{2}{*}{$\underset{>}{\text { Group III }}$} & . & . & . & $38 \cdot 1$ & $19-59$ & 22 & 21 & $11 \cdot 7$ & $0 \cdot 7-31$ & $7 \cdot 3$ & $0 \cdot 3-23$ \\
\hline & & Total & . & 35 & $15-59$ & 39 & 83 & 8 & $0 \cdot 1-31$ & $4 \cdot 8$ & $0 \cdot 1-23$ \\
\hline
\end{tabular}

subdivided according to their jobs and to the month of onset of the disease, in order to evaluate whether or not the activity influenced the period in which the disease manifested itself (Fig. 2).

The polyneuropathy is prevalent during the early months of the year, regardless of the job performed, suggesting that the responsible agent might be the same in each job.

\section{Observations concerning the work places}

The most significant and constant elements that emerged from our visits to the factories where cases of polyneuropathy were found were:

the disease was almost always found in very small factories with fewer than 20 workers;

the work place was often a single, very small room, at ground level or in a basement. In the cold months the doors and windows were kept closed during work;

all the leathers, glues, solvents, and the parts already glued or cleaned with solvents were kept in the work room. The glues and solvents were kept in open widemouthed containers on the work table, very close to the people who used them;

all the work places lacked devices for eliminating gaseous pollutants and for ensuring an adequate air change;

because of the small dimensions of the work places, the workers were close to each other and, therefore, even workers who had no direct contact with glues or solvents were exposed to high concentrations of vapours;

none of the workers was aware of the possible hazards from exposure to the substances used, and personal hygiene was very poor.

\section{Discussion}

The most significant elements that emerge from our study are that: the frequency of the disease is steadily increasing and polyneuropathy in its more serious form manifests itself most frequently during the early months of the year. Even though the disease more frequently affects workers involved in glueing, it also affects those involved in cleaning 


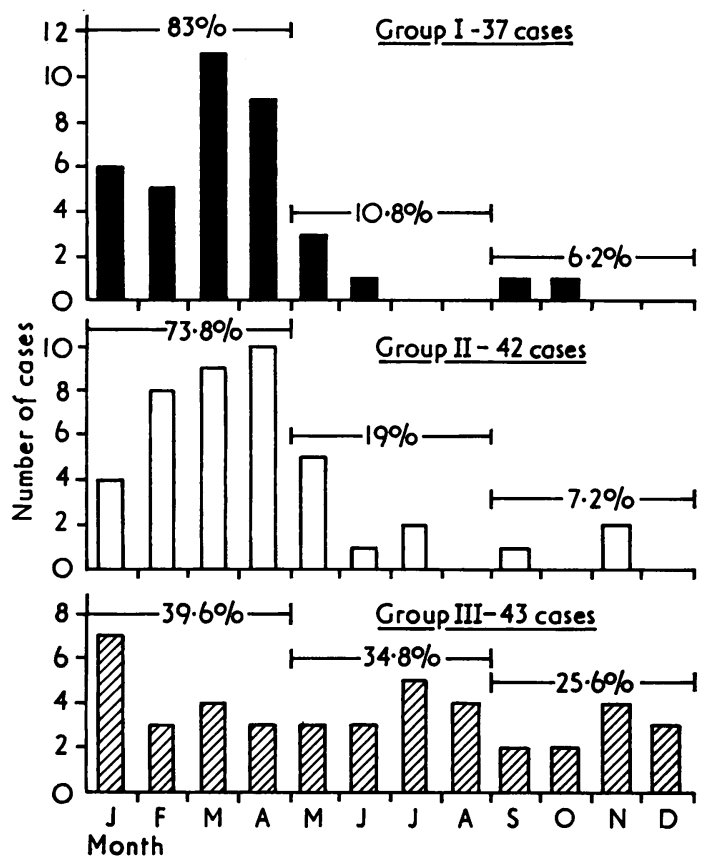

FIG. 1. Relationship between the severity of disease and month of onset of polyneuropathy.

the shoes with solvents and even those who have no direct contact with either paste adhesives or solvents. The disease is found almost exclusively among workers in small shoe factories, of the artisan type, where standards of hygiene are low.

These data cast doubt on the hypothesis that the agent responsible for the disease is contained only in the paste adhesives and is absorbed through the skin (Cappellini et al., 1968). These observations limit, in our opinion, the importance of TOCP as the causative agent of the disease. In addition, analyses of many samples of glues and leathers taken in factories where cases of polyneuropathy occurred, showed that TOCP was either absent or present in negligible quantities (Crepet et al., 1968; Cappellini et al., 1968).

It seems more probable that the disease is caused by volatile substances that accumulate in the working environment under conditions of poor hygiene. The most likely hypothesis is that the primary causative agents are paraffin hydrocarbons of low boiling point (pentane, hexane, heptane, and isomers), without excluding at the moment the importance of other volatile and non-volatile substances present in the materials used.

This hypothesis is supported by the following evidence:

These hydrocarbons are able to cause a polyneuropathy as has been recently demonstrated in

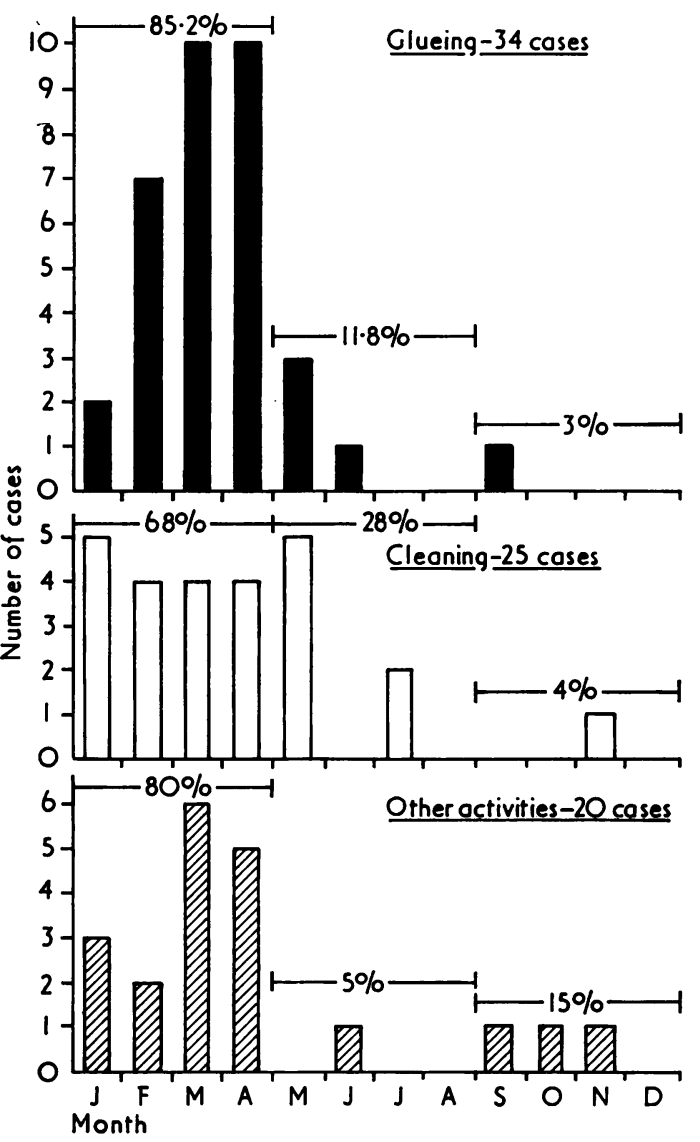

FIG. 2. Relationship between activity and month of onset of polyneuropathy (Groups I and II).

experimental studies (Kurita, 1967; Truhaut et al., 1973).

They have been found in very high concentrations (more than $80 \%$ of the total solvent) in glues and cleaning fluids collected by us from five different factories which had a total of 20 workers affected by the disease (Table 5). They were also present in similar concentrations in a glue considered responsible for $\mathbf{4 0}$ cases of polyneuropathy which occurred in Naples in 1973 (Collettivo mediciingegneri contro la nocività, 1974).

An investigation conducted in shoe factories in the Marche region (Alberti, 1972, personal communication), where most of our patients came from, showed that in $75 \%$ of the work places examined the concentration of these substances was much higher than the threshold limit value proposed by the American Conference of Governmental Industrial Hygienists.

There are many similarities between our findings and those of Japanese authors who reported cases 
TABLE 5

Composition of Solvents and Glues used in Five Factories with a Total of 20 Cases of POLYNEUROPATHY

\begin{tabular}{|c|c|c|c|c|c|c|c|c|c|}
\hline & & \multirow{4}{*}{$\begin{array}{l}\text { Boiling } \\
\text { point } \\
\left(\mathbf{C}^{\circ}\right)\end{array}$} & \multicolumn{7}{|c|}{ Solvent composition ( $\%$ by weight) } \\
\hline & & & & & & Factori & & & \\
\hline & & & & & 2 & & & 4 & 5 \\
\hline \multicolumn{2}{|c|}{ Solvent components } & & Glue & Glue & Cleaner & Glue & Glue & Cleaner & Glue \\
\hline \multirow[t]{2}{*}{$\begin{array}{l}\text { Paraffin } \\
\text { hydrocarbons .. }\end{array}$} & 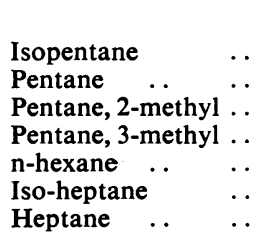 & $\begin{array}{l}31 \\
36 \\
60 \\
64 \\
69 \\
95 \\
98\end{array}$ & $\begin{array}{r}2.4 \\
38.1 \\
46.3 \\
\\
8.4\end{array}$ & $\begin{array}{l}10 \cdot 5 \\
71 \cdot 6 \\
\\
13 \cdot 1\end{array}$ & $\begin{array}{r}0 \cdot 4 \\
23 \cdot 7 \\
62 \cdot 2\end{array}$ & $\begin{array}{l}37 \cdot 9 \\
49 \cdot 7\end{array}$ & $\begin{array}{r}11.5 \\
44.9 \\
0.9 \\
10.1 \\
1.1 \\
6.6\end{array}$ & $\begin{array}{c}\text { traces } \\
\begin{array}{c}30 \\
49 \cdot 3\end{array}\end{array}$ & $\begin{array}{l}0.2 \\
21 \\
60.6\end{array}$ \\
\hline & Total & & 95 & 95 & 86 & 88 & 89 & 79 & 82 \\
\hline \multirow[t]{2}{*}{ Cyclic hydrocarbons } & $\begin{array}{l}\text { Cyclopentane } \\
\text { Cyclopentane, methyl } \\
\text { Cyclohexane } \quad . .\end{array}$ & $\begin{array}{l}50 \\
72 \\
80\end{array}$ & $2 \cdot 2$ & $2 \cdot 2$ & $\begin{array}{c}0.44 \\
13 \cdot 2\end{array}$ & $\stackrel{12}{0.5}$ & $\begin{array}{l}4 \cdot 2 \\
2 \cdot 7 \\
4\end{array}$ & $\begin{array}{c}0.4 \\
17 \\
0.9\end{array}$ & $\begin{array}{r}0.3 \\
17 \cdot 4 \\
0 \cdot 6\end{array}$ \\
\hline & Total & & 2 & 2 & 14 & 12 & 11 & 18 & 18 \\
\hline Other & $\begin{array}{lll}\text { Toluene } & . & \ldots \\
\text { MBK etc. } & . . & \ldots\end{array}$ & & $2 \cdot 5$ & $2 \cdot 6$ & & traces & traces & $2 \cdot 4$ & \\
\hline
\end{tabular}

of polyneuropathy attributed to n-hexane (Yamada, 1967; Miyagaki, 1967; Sobue et al., 1968; Inoue et al., 1970). These similarities include the type of work, the clinical picture, the epidemiological data, the poor hygienic conditions of the work places, and the composition of the solvents used.

Methyl n-butyl ketone (MBK) another industrial solvent, recently shown to cause peripheral polyneuropathy in man and in experimental animals (McDonough, 1974; Journal of the American Medical Association, 1974; Mendell et al., 1974; American Industrial Hygiene Association Journal, 1975; Spencer et al., 1975) has not been found in glues or solvents taken from shoe factories analysed by us.

The hypothesis that could explain the occasional occurrence of shoe-makers' polyneuropathy is that the disease is caused by factors acting together.

Important factors are the use of glues and/or solvents containing paraffin hydrocarbons with a low boiling point (pentane, 2-methyl-pentane, 3methyl-pentane, hexane, heptane, etc.); poor environmental hygiene (small work places without any system for removing toxic vapours), and bad personal hygiene. These factors alone may be insufficient to provoke the disease which is precipitated when other factors are also present.
These additional conditions are the use of glues and/or solvents with an exceptionally high content of paraffin hydrocarbons with a low boiling point; increased environmental pollution such as occurs during the cold season as a result of closed doors and windows; the occasional presence of other neurotoxic substances in the materials, the role of which cannot for the present be excluded from the aetiology of the disease.

There are numerous indications that the paraffin hydrocarbons with low boiling points are the principal causes of the disease.

It is not at present clear, however, whether only one of these substances or the combined action of several hydrocarbons of the same group is responsible.

It is also not known why the disease sometimes occurs in a form so mild as to permit normal or almost normal work for months, while at other times it evolves rapidly and causes complete paralysis of the limbs within one to two months. It is possible that this effect is due to differences in the quantity of the toxic vapours absorbed by the workers, as a consequence of diversity in environmental pollution of work places.

Further experimental, clinical, and epidemiological studies are necessary to answer these aspects of the problem. 
The authors wish to thank Dr J. M. Barnes and Mrs P. M. Edwards, MRC Toxicology Unit, Carshalton, UK, for their valuable comments and for reviewing the manuscript.

\section{References}

Ambrosetto, C. (1968). Su particolari manifestazioni polineuritiche collegate con probabile assorbimento percutaneo di T.O.C.P. In Proceedings of the $X X X I$ Italian Congress of Occupational Health, pp. 122-131. Istituto di Medicina del Lavoro, Policlinico S. Orsola, Bologna, Italy.

American Industrial Hygiene Association Journal (1975). Methyl n-butyl ketone studies. 36, 153-158.

Barone, A., Dell'Aria, V., Fasanaro, G., Sepe, O., and Tecce, V. (1973). Nosologia e tentativi di depistage della polineuropatia da collanti. From the Summaries of The Proceedings of the XVIII Congress of the Italian Neurology Society, Rome, 5-8 December, pp. 75-76.

Battistini, N., Zanette, E., Battista, F., Franzinelli, A., Fieschi, C., Lenzi, G. L., and Bergamini, E. (1973). Osservazione di un gruppo di polineuropatie da collanti. From the Summaries of The Proceedings of the XVIII Congress of the Italian Neurology Society, Rome, 5-8 December, p. 74.

Borri, P., Cianchetti, C., and Gainotti, G. (1967). Su alcuni casi di polinevriti tossiche provenienti da calzaturifici della regione Marchigiana. Annali Facoltà di Medicina e Chirurgia di Perugia, 58, 491-497.

Cappellini, A., Chiappino, G., and Zurlo, N. (1968). Osservazioni cliniche e sperimentali sulle polinevriti cosidette da Tricresilfosfati. In Proceedings of the $X X X I$ Italian Congress of Occupational Health, pp. 53-99. Istituto di Medicina del Lavoro, Policlinico S. Orsola, Bologna, Italy.

Carnevale, F., Costa, G., D'Andrea, F., Faggionato, G., and Perbellini, L. (1973). Nuova ipotesi sulla etiologia delle polineuropatie 'da collanti'. Folia Medica, 56, 11-16.

Collettivo medici-ingegneri contro la nocività. Le lotte a Napoli (1974). Sapere-n. 774, 83-85. Edizioni DedaloItalia.

Crepet, M., Gaffuri, E., Picotti, G., and Carli, A. (1968). Patologia da arilfosfati nell'industria delle calzature. In Proceedings of the XXXI Italian Congress of Occupational Health, pp. 41-52. Istituto di Medicina del Lavoro, Policlinico S. Orsola, Bologna, Italy.

Del Greco, V. and Cecchini, S. (1966). Neuropatia periferica tossica da adesivi gommosi. Rivista di Neurobiologia, 1, 93-108.

D'Errico, T., De Pedrini, L., Perrelli, G., and Bonzanino, A. (1968). Osservazioni su alcuni casi di intossicazione professionale da T.O.C.P. In Proceedings of the XXXI Italian Congress of Occupational Health, pp. 344-355. Istituto di Medicina del Lavoro, Policlinico S. Orsola, Bologna, Italy.

Fabiani, P. and Bedogni, G. (1962). Quoted by Leoni, G. (1967).

Faggi, L., Cosi, V., and Cavalleri, S. (1971). Le polinevriti da collanti industriali; studio clinico ed elettromiografico. Rivista di Neurologia, 41, 119-125.
Gatti, B. and Saraval, A. (1960). Quoted by Leoni, G. (1967).

Gherardi, M. (1965). Le polinevriti da Triarilfosfati nell'industria delle calzature. Artis Medicae Studia, 29, 47-66.

Graev, M., Cecere, U., and Froldi, R. (1971). Illustrazione di 8 casi di polinevriti da T.O.C.P. e sua dimostrazione chimica in un composto plastificante "celloresina" usato in una conceria. Rivista Infortuni e Malattie Professionali, 1, 53-73.

Inoue, T., Takeuchi, S., Yamada, S., Suzuchi, H., Matsushita, T., Miyagaki, H., Maeda, K., and Mathsumoto, T. (1970). A health survey on vinyl sandal manufacture with high incidence of n-hexane intoxication. Japanese Journal of Industrial Health, 12, 73-84.

Isotti, M. and Saraval, A. (1957). Su di una epidemia di polinevrite motoria da intossicazione. Bollettino Società Medica Chirurgica di Pavia, 1, 131-133.

— and - (1958). Quoted by Leoni, G. (1967).

Journal of the American Medical Association (1974). Medical news. Solvent causes motor neuropathy in workers at clothing factory, 229, 247-248.

Kurita, H. (1967). Experimental studies on the effects of $\mathrm{n}$-hexane to albino rats. Japanese Journal of Industrial Health, 9, 672-677.

Leoni, G. (1967). Il problema delle polinevriti attribuite a collanti industriali. Rivista Sperimentale di Freniatria, 91, 1010-1029.

McDonough, J. R. (1974). Possible neuropathy from methyl n-butyl ketone. New England Journal of Medicine, 290, 695.

Marroni, M. (1968a). Su di un caso di intossicazione collettiva familiare da esposizione lavorativa a T.O.C.P. In Proceedings of the XXXI Italian Congress of Occupational Health, pp. 336-340. Istituto di Medicina del Lavoro, Policlinico S. Orsola, Bologna, Italy.

(1968b). Su di un caso di malattia professionale da T.O.C.P. in un'operaia di conceria. In Proceedings of the XXXI Italian Congress of Occupational Health, pp. 341-343. Istituto di Medicina del Lavoro, Policlinico S. Orsola, Bologna, Italy.

Maugeri, S. and Candura, F. (1968). La nostra esperienza in tema di patologia da cresilfosfati. In Proceedings of the XXXI Italian Congress of Occupational Health, pp. 100-121. Istituto di Medicina del Lavoro, Policlinico S. Orsola, Bologna, Italy.

Mazzella di Bosco, M. (1964). Su alcuni casi di intossicazione professionale da T.O.C.P. Lavoro Umano, 16, 267-275.

Mendell, J. R., Saida, K., Ganansia, M. F., Jackson, D. B., Weiss, H., Gardier, R. W., Chrisman, C., Allen, N., Couri, D., O’Neill, J., Marks, B., and Hetland, L. (1974). Toxic polyneuropathy produced by methyl n-butyl ketone. Science, 185, 787-789.

Miyagaki, H. (1967). Electrophysiological studies on peripheral neurotoxicity of n-hexane. Japanese Journal of Industrial Health, 9, 660-671.

Montanari, M. (1976). Considerazioni clinico-statistiche e prognostiche sulle polineuropatie da collanti nella provincia di Verona. Communication to The XVIII Congress of the Italian Neurology Society, Rome, 5-8 December 1973. (In press). 
Pinelli, P. and Tonali, P. (1964). Studi seriali elettromiografici delle polinevriti. Rivista Patologia Nervosa e Mentale, 85, 345-385.

Pretolani, E. and Scotti, M. (1963). Indagine elettroencefalografica in corso di polinevriti tossiche (da T.O.C.P.). Rivista Infortuni e Malattie Professionali, 50, 357-366.

Ruggerini, C. and Teso, G. A. (1968). Episodio di intossicazione collettiva riferita a T.O.C.P. In Proceedings of the XXXI Italian Congress of Occupational Health, pp. 330-334. Istituto di Medicina del Lavoro, Policlinico S. Orsola, Bologna, Italy.

Sobue, I., Yamamura, Y., Ando, K., Iida, M., and Takayanagy, T. (1968). N-hexane polineuropathy. Clinical Neurology (Tokyo), 8, 393-403.

Spencer, P. S., Schaumburg, H. H., Raleigh, R. L., and
Terhaar, C. J. (1975). Nervous system degeneration produced by the industrial solvent methyl n-butyl ketone. Archives of Neurology, 32, 219-222.

Truhaut, R., Laget, P., Piat, G., Nguyen Phu-Lich, Dutertre-Catella, H., and Vu Ngog Huyen (1973). First electrophysiological results after experimental intoxication with technical hexane and heptane in the albino rat. Archives des Maladies Professionelles, 34, 417-426.

Yamada, S. (1967). Intoxication polyneuritis in the workers exposed to n-hexane. Japanese Journal of Industrial Health, 9, 651-659.

Received for publication 24 April 1975.

Accepted for publication 7 August 1975. 